\title{
ナイロン66繊維の過酸化ジクミルおよび 過酸化ベンゾイルによる架橋*
}

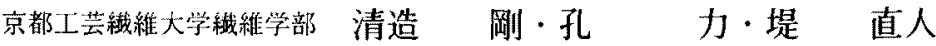

\section{Crosslinking of Nylon 66 Fiber by Dicumyl Peroxide and Benzoyl Peroxide}

Tsuyoshi Kiyotsukuri, Li Kong, and Naoto Tsutsumi

Department of Polymer Science and Engineering, Kyoto Institute of Technology,

Matsugasaki, Sakyo-ku. Kyoto, 606 Japan

\begin{abstract}
Commercial nylon 66 fibers were dipped in a chloroform solution of dicumyl peroxide (DCP) or benzoyl peroxide $(\mathrm{BPO})$ at $60 \sim 65^{\circ} \mathrm{C}$ under $\mathrm{N}_{2}$ atmosphere for predetermined times and then crosslinked at $150{ }^{\circ} \mathrm{C}$ for $2 \mathrm{~h}$. The crosslinked fibers became partially insoluble in hot formic acid after dipping for 5 days for DCP and 3 days for BPO. By this crosslinking treatment the crystalline region was also affected. Reduced specific viscosity of crosslinked fibers decreased with the increase in crosslinking temperature and time of dipping, showing that the crosslinking of molecular chains occurred abreast with decomposition of main chains. Density and Young's modulus of crosslinked fibers in creased, but tenacity and elongation decreased with the increase in time of dipping. The degrees of these increases and decreases were more remarkable for BPO than DCP.
\end{abstract}

(Received April 8. 1992)

\section{1. 粕言}

轹維材料を産業分野に利用する場合には，用途に応じ て, 高酎熱性, 高酎熱変形性, 低クリープ, 高强度, 高 弾性率，高耐薬品性などの，衣料用絨維よりも高度な性 能が要求される。このような高性能化を目指した改質法 の一つに架橋の導入がある。架橋の手段には，従来から 放射線や電子線などの高エネルギ一線源を用いる力法 と，ホルムアルデヒドや過酸化物などの架橋剮を用いる 方法がある[1]。線状ポリマーのメチレン鎖が過酸化物 の作用で架橋することは，ポリエチレンやポリプロピレ

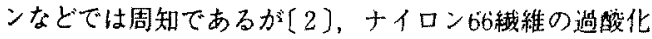
物による架橋については，清造ら（3）によって初めて報 告された。ナイロン66减維を過酸化ジクミルのクロロホ ルム溶湾中で還流下に5 日以上浸漬したのち，150 Cで 2 時間架橋処理を行うと、キ酸に部分的に不溶となって，

ここの報文を「合成維維の過酸化物による架满（第1

報)，Crosslinking of Synthetic Fibers by Peroxides (Part 1)」とする。
桟維のヤング率が顕著に上昇し，また吸水しても強度と 伸度が低下しなくなることが見出された。

本研究では，過酸化物として架橋のために浸瀆に5日 以上の長時間を必要とする過酸化ジクミルのはかに，架 椅効率がより高いと考えられる過酸化ベンゾイも使用 して，浸䟺条件や架橋処理条件をより店範用に変化さ せ，これらの諸条件がナイロン66䄉維の楧造と性質に及 ぼす影謷を詳練に検傠した結果について報告する。

\section{2. 実験法}

\section{1 試 料}

ナイロン66緎維（70デニール，247イラメント）は市 眨品をそのまま使用した。

過酸化物には，過酸化ジクミル(以下 DCPと略す) と過酸化ベンゾイ（以下 BPOと略す）の市販の特級 試薬をそのまま使用した。

浸䟺液の溶媒には，クロロホルムの市販の特級試薬を そのまま使用した。

溶解性試験用のギ酸と粘度測定用の濃硫酸は, 市貶の 特級試薬をそのまま使用した。 


\section{2 浸婊および架樗処理法}

䋘維を過酸化物の飽和状態に近いクロロホルム溶液 (DCP は $30 \mathrm{wt} \%$ ，BPOは $15 \mathrm{wt} \%)$ に浸漬し， $\mathrm{N}_{2}$ を導入 して $60^{\circ} \mathrm{C}$ - $65^{\circ} \mathrm{C}$ で所定時間保持することによって過酸 化物を䄉維中に含浸させたのち, 取り出して所定温度で 2 時間加熱して架橋処理を行った。引張試験用試料は, 䄉維をガラス棒で作った枠に平行に巻き付けて固定して から，上記の処理を行った。比較のために，過酸化物を 加えないで24時閵浸漬し， $150{ }^{\circ} \mathrm{C} て ゙ 2$ 時間熱処理した試 料をコントロール試料として使用した（図中では浸漬時 間 $0 \mathrm{~h}$ として表す)。

\section{3 溶解性試㰸}

$10 \mathrm{mg}$ の架橋処理試料に対してギ酸 $0.5 \mathrm{~mL}$ 学加え, 室温で観察し，24時間保持しても溶解しない場合は, 加 熱してその状態を観察した。

\section{4 示差熱分析法 (DTA)}

島津 DT-30型示差熱分析装置を使用し，試料量 $5 \mathrm{mg}$, 昇温速度 $10^{\circ} \mathrm{C} / \mathrm{min}$ で $\mathrm{N}_{2}$ 中で測定した。

\section{5 筑重量惻定法 (TG)}

島津 DT-30型熱重量測定装置を使用し，試料量 $8 \mathrm{mg}$, 昇温速度 $10^{\circ} \mathrm{C} / \mathrm{min}$ で $\mathrm{N}_{2}$ 中で測定した。

\subsection{X線測定法}

東芝 $A D G-301$ 型X線回折装置を使用し，Niフィルタ 一を用いて Cuk ${ }_{a}$ 線で測定した。䄉維は細かく切断して 測定に供した。

\section{7 粘度椡定法}

絶乾試料 $0.05 \mathrm{~g}$ を $10 \mathrm{~mL}$ の濃硫酸に溶解し,ウベロー デ型粘度計を使用し， $30^{\circ} \mathrm{C}$ で測定した。

\section{8 密度酒定法}

nーヘプタン /四塩化炭素系の密度勾配管を使用し， $30{ }^{\circ} \mathrm{C}$ で試料投入後，24時間後の值を読み取った。

\section{9 引张試悇法}

岩本製作所製引張試験機を使用し，試料長 $20 \mathrm{~mm}$, 引 張速度 $125 \% / \mathrm{min}$ で測定した。

\section{3. 結果と考察}

\section{1 溶解性試検}

DCP の30wt\%のクロロホルム溶液に所定時間浸漬し たのち， $150^{\circ} \mathrm{C} て ゙ 2$ 時間架橋処理した試料は，浸漬時間 5 日以上のものはギ酸に部分的に不溶となった。一方, BPOの15wt\%のクロロホルム溶液に浸漬し， $150^{\circ} \mathrm{C} て ゙ 2$ 時間架橋処理した試料は，浸漬時間 3 日以上のものはギ 酸に部分的に不溶となり，BPOのほうがより低濃度で あっても架槁により有効であることが判明した。過酸化 物の架橋効率を表す理論活性酸素量と半隇期 1 分の分解 温度はそれぞれ DCP が5.92\%と $171{ }^{\circ} \mathrm{C}$ ，BPOが6.62\%

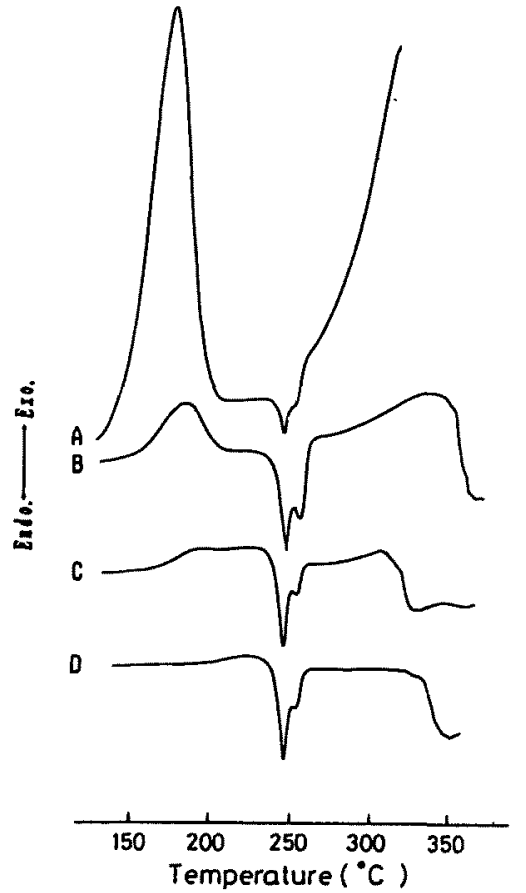

Fig. 1 DTA curves of crosslinked fibers : Dipped in a chloroform solution of DCP for 10 days; crosslinked for $2 \mathrm{~h}$ at (A) $110^{\circ} \mathrm{C},(\mathrm{B}) 130^{\circ} \mathrm{C}$, (C) $150^{\circ} \mathrm{C}$, (D) $170{ }^{\circ} \mathrm{C}$.

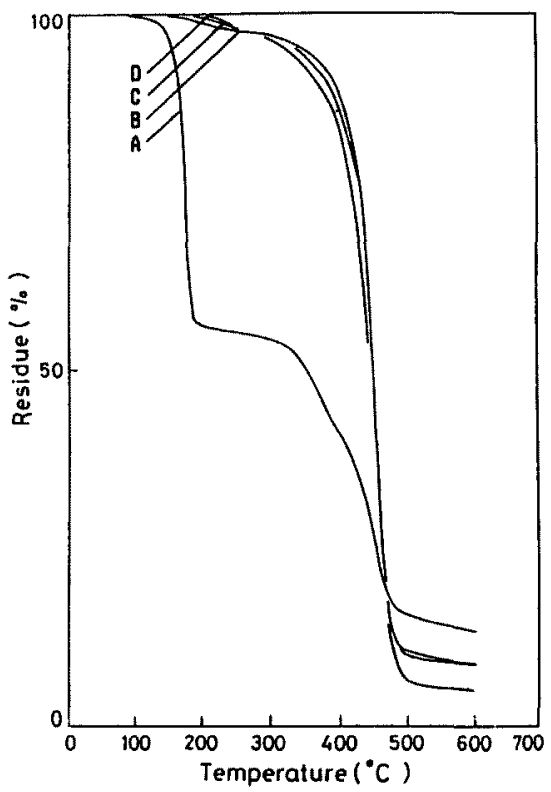

Fig. 2 TG curves of crosslinked fibers: Dipped in a chloroform solution of DCP for 10 days. A, B, C and D are the same as shown in Fig. 1. 


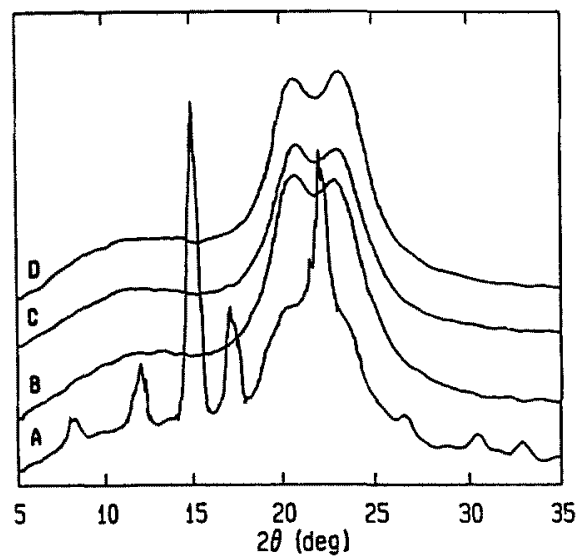

Fig. 3 X-Ray diffraction intensity curves of crosslinked fibers: Dipped in a chloroform solution of DCP for 10 days. A, B, C and D are the same as shown in Fig. 1.

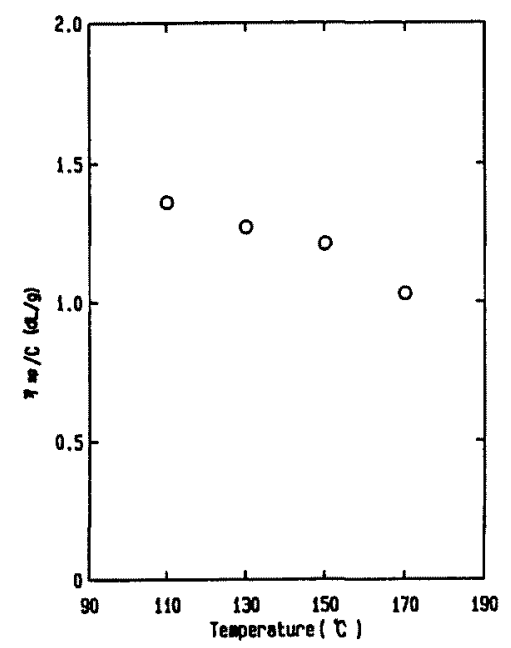

Fig. 4 Relationship between $\eta{ }_{s p} / C$ and crosslinking temperature for fibers dipped in a chloroform solution of DCP for 1 day.

と133 Cであり[4]，BPOのほうがより短時間で部分的 に不溶化した原因はBPOの架橋効率がより高いことに 㷌せられよう。

\section{2 架權约理温度の影空}

DCPに10日浸濵し，110，130，150および170 ${ }^{\circ} \mathrm{C} て 2$ 時間架樀処理した試料の DTA 曲線とTG 曲線をそれぞ れ図 1 と図 2 に示す。図 1 のAの110 $\mathrm{C}$ の DTA 曲楾に は，融解の前に顕著な発熱ピークが観察される。架橋処 理温度が上昇するとこの発熱ピークは急激に小さくな ク，Dの170 Cではほほ消失した。これに対応して，间 2 の $\mathrm{A} 110^{\circ} \mathrm{C} の \mathrm{TG}$ 曲線には，顕著な 2 段階分解が覥
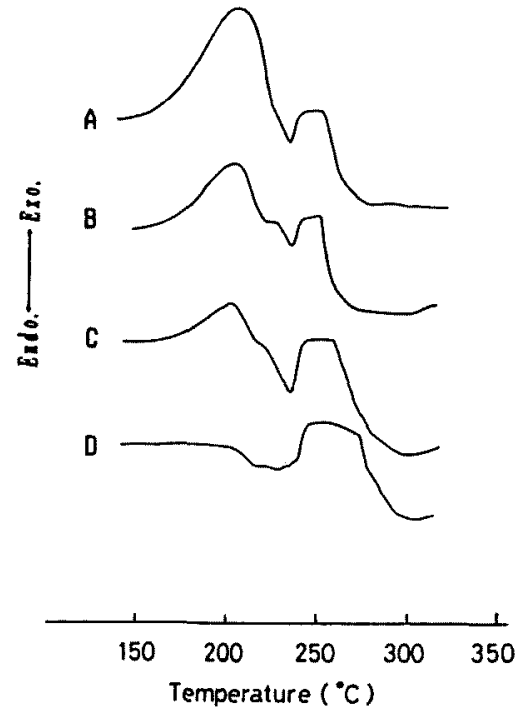

Fig. 5 DTA curves of crosslinked fibers: Dipped in a chloroform solution of $\mathrm{BPO}$ for 10 days; crosslinked for $2 \mathrm{~h}$ at (A) $110^{\circ} \mathrm{C},(\mathrm{B}) 130^{\circ} \mathrm{C}$, (C) $150^{\circ} \mathrm{C}$. (D) $170{ }^{\circ} \mathrm{C}$.

察される。架橋処理温度が上昇すると，1段目の分解の 量が急激に隇少している。この現象の原因を解明するた めに, DCPのみについてDTAと TG 测定を行った。そ の結果, DCPのみの DTA 曲線には，DCPの熱分解に起 因すると考えられる大きな発熱ピークが175 C 付近に観 察された。この結果から，試料のDTA 曲線の融解前に 出現した発熱ピークは織維中に残存する末反応の DCP の分解によるるのと推定される。また，図2のAの110 'Cの試料の1段目の分解温度は DCPのみの TG 曲線の 分解温度と同じ温度で出現している。このことから， TG 曲線の最初の重量損失は, 残存する未反応の DCP の分解による脱離に起因すると考えられる。架橋処理温 度が $130{ }^{\circ} \mathrm{C}$ 以上では，残存する末反応の DCP の量が急 激に隇少するために，TG曲線の1段目の重量損失も極 端に減少している。同じ条件で処理した試料のX線回折 強度曲線を図 3 に示す。架橋処理温度がAの110 $\mathrm{C}$ の場 合には，残存するDCPの結晶に起因する鋭い回折ピー クが出現しているが， Bの $130^{\circ} \mathrm{C}$ 以上ではこれらのピー クは消失しており，DTA TGの結果とよく対応して いる。

DCPに1 日浸漬し，110，130，150および170 ㄷで2 時間架橋処理した試料の粘度测定の結果を四 4 に示す。 架楴処理温度の上昇にともなって, 試料の還元比粘度の 值が低下している。このことから，十イロン66䋐維が過 酸化物によって架橋するとき，同時に主鎖の分解も進行 


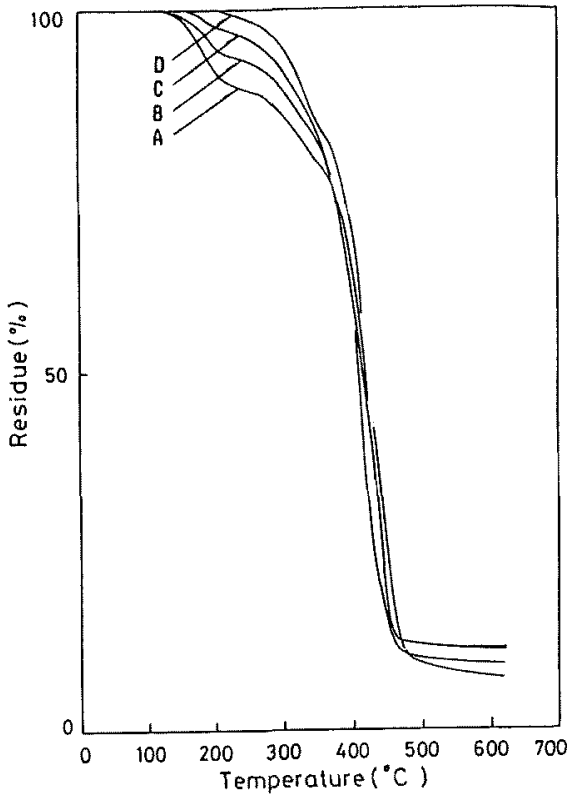

Fig, 6 TG curves of crosslinked fibers: Dipped in a chloroform solution of BPO for 10 days. A, B, C and D are the same as shown in Fig. 5.

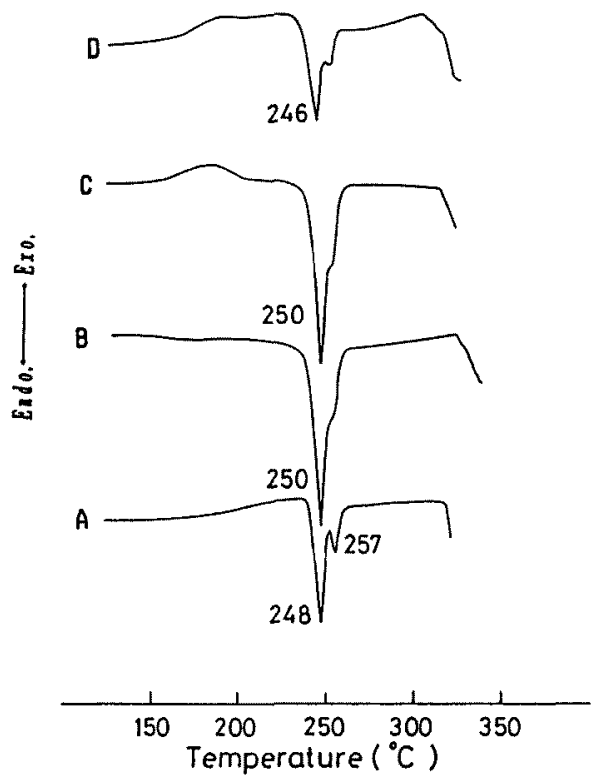

Fig. 7 DTA curves of fibers dipped in a chloroform solution of DCP and crosslinked at $150^{\circ} \mathrm{C}$ for $2 \mathrm{~h}$; Time of dipping (A) $0 \mathrm{~h}$, (B) $2 \mathrm{~h}$. (C) 2 days, (D) 10 days.

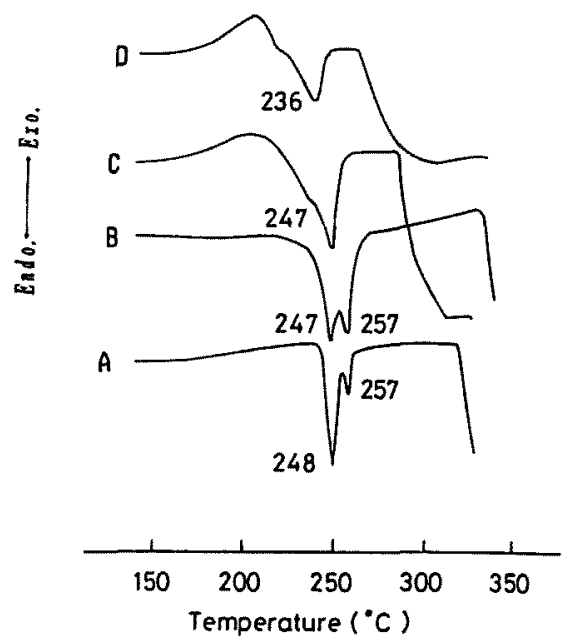

Fig. 8 DTA curves of fiber dipped in a chloroform solu. tion of BPO and crosslinked at $150{ }^{\circ} \mathrm{C}$ for $2 \mathrm{~h}, \mathrm{~A}, \mathrm{~B}, \mathrm{C}$ and $\mathrm{D}$ are the same as shown in Fig. 7.

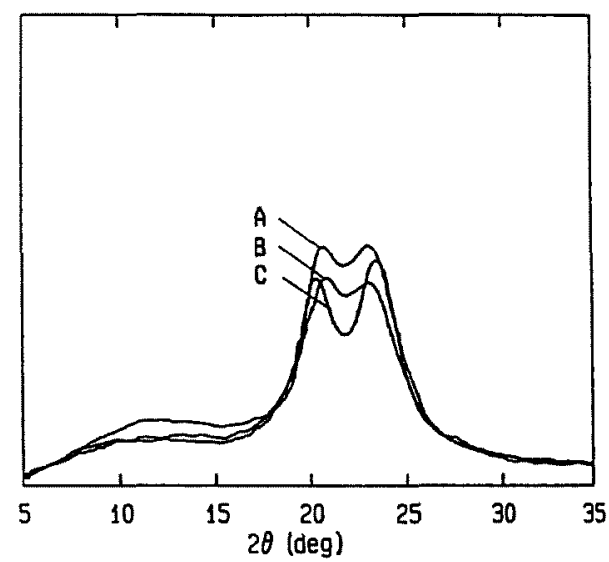

Fig. $9 X$-Ray diffraction intensity curves of fibers: Dipped in a chloroform solution of peroxide for 10 days and crosslinked at $150{ }^{\circ} \mathrm{C}$ for $2 \mathrm{~h}$ : (A) control sample, (B) DCP, (C) BPO.

することが判明した。架橋好理温度が上昇すると主鎖の 分解も促進される。

BPOに10日浸清し，110，130，150および170 Cで2 時間架橋処理した試料のDTAと TG曲線をそれぞれ図 5 と図 6 に示す。BPOのみのDTA曲線には融解が始ま ると直ちに分解して発熟する特徽が見られ，BPOの架 橋効率が高いことと関連しているようである。150 C以 下の温度で架橋処理した試料A C の図 5 のDTA曲線 には，融解の前に発熱ピークが観察される。图6のTG 曲線に执いても，2段階の分解が観祭される。これらの 


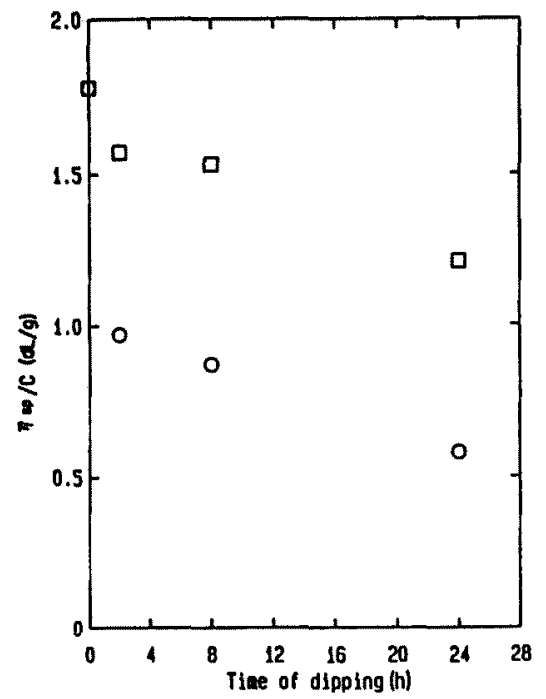

Fig. 10 Relationship between $\eta_{\mathrm{sp}} / \mathrm{C}$ and time of dipping for fibers dipped in chloroform solutions of DCP and $\mathrm{BPO}$ and crosslinked at $150{ }^{\circ} \mathrm{C}$ for $2 \mathrm{~h}$ : ( $\square$ ) DCP, ( O) $\mathrm{BPO}$.

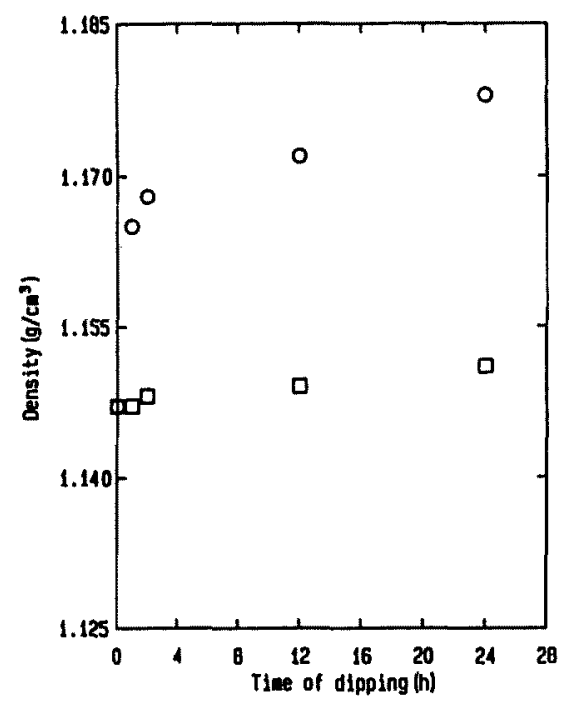

Fig. 11 Relationship between density and time of dipping for fibers dipped in chloroform solutions of DCP and $\mathrm{BPO}$ and crosslinked at $150{ }^{\circ} \mathrm{C}$ for $2 \mathrm{~h}$. ( $\square$ ) DCP. (O) $\mathrm{BPO}$.

現象は上記したDCPの場合とよく対応しており, 残存 する末反応の BPO の熱分解に起因すると考えられる。

\section{3 涅注時间の影要}

DCP および BPOによる架橋処理試料の浸漬時間によ

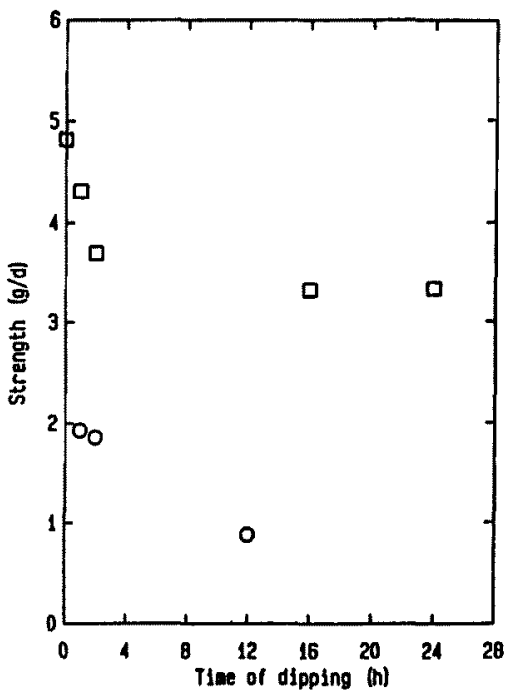

Fig. 12 Relationship between tensile strength and time of dipping for fibers dipped in chloroform solutions of DCP and BPO and crosslinked at $150{ }^{\circ} \mathrm{C}$ for 2 h. ( $\square$ ) DCP, (O) BPO.

るDTA 曲線の変化をそれぞれ図 7 および図 8 に示す。 両者ともより長時閧浸瀆した試料では，融解前に発熱ピ 一クが観察されるがここれ前節で示したように残存す る未反応の過酸化物の熱分解に起因しており，浸漬時間 が増加すると含浸される過酸化物の量が増加するため に，末反応の量も增加すると考えられる。次に，浸漬時 間の增加にともなって，融点がやや降下している。この 現象を検討するために，10日浸漬し，架橋処理した試料 のX線分析を行った。るその結果を図9に示す。10日浸漬 し，架桥処理した試料の回折ピーク強度はAのコントロ 一ル試料よりも低下しており，非晶領域に含浸された過 酸化物によって架橋が形成されるとき，結晶領域も影響 を受けることを示している。その影響の程度はDCPよ りも BPOのほうが大きく, 融点の降下が図8のBPOの ほうが大きいことと対応している。

DCP および BPO による架橋処理試料の漫漬時間によ る還元比粘度の変化を図10に示す。両者とも浸漬時間の 增加にともなって，噵元比粘度の值が低下している。過 酸化物は架橋剂としての役割を果たす一方，主鎖の分解 も生じることを先に図4で示したが，浸漬時間の增加に 对しても，過酸化物の含浸量が増加して主鎖の分解が促 進され，逻元比粘度の值が低下したと考えられる。この 場合に，DCPに比べて BPOのほうが還元比粘度の值が より低下しており，BPOのはうが主鎖をより分解しゃ すいことが判明した。 


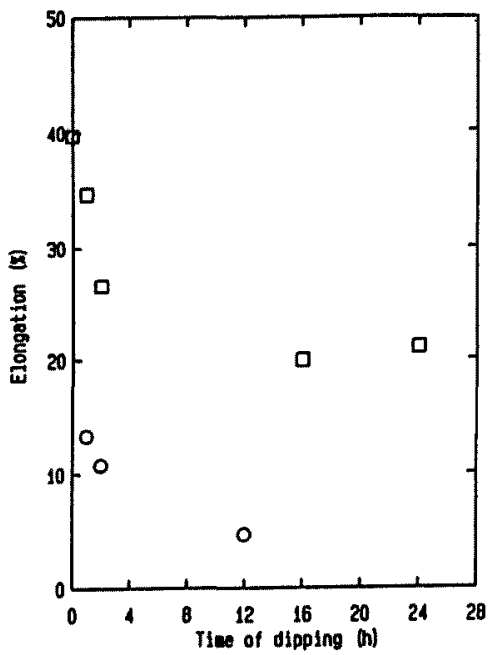

Fig. 13 Relationship between elongation and time of dipping for fibers dipped in chloroform solutions of DCP and $\mathrm{BPO}$ and crosslinked at $150{ }^{\circ} \mathrm{C}$ for $2 \mathrm{~h}$. ( $\square$ ) DCP. (O) BPO.

DCP および BPOによる架櫑処埋試料の浸瀆時間によ る密度の変化を図11に示す。両者とも密度が浸漬時間の 增加とともに増加している。これは非晶領域中の分子鎖 が架橋を形成することによって互いに接近するためと考 えられる。DCPに比べて BPOのほうが密度が高い值を とっており，BPOのほうが架橋の程度が高いと推定さ れる。

DCP および BPOによる架橋処理試料の强度, 伸度お よびヤング率の浸漬時間による変化を図12１4にに示す。 両者とも浸漬時間の增加にともなって，強度と伸度が低 下し，ヤング率が上年している。強度と伸度の低下は， 図10で示した主鎖の分解に起因すると考えられるが、こ の場合に，僄元比粘度の低下がより大きいBPOのほう が強度と伸度の低下がより顕著であり，よく対応してい る。なお，BPOでは16時間以上浸漬すると找維がも万 くて強伸度の測定が不可能となった。一方, ヤング率 は，浸漬時間が增加すると，強伸度が低下するにもかか わらず，上昇している。ヤング率の上昇は，架橋結合の 導入によって，分子鎖の内部回転が㧕制されるためと考 えられ，このような小変形領域の挙動は強伸度のような 大変形領域の举動とは对応しないのであろう。BPOで は2 倍以上にヤング率が上昇しており注目されるが, 強 伸度の低下が大きい点に問題があるう。

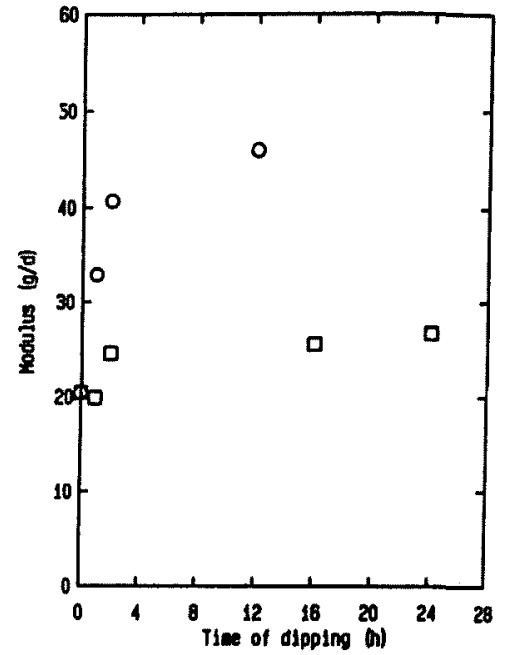

Fig. 14 Relationship between modulus and time of dipping for fibers dipped in chloroform solutions of DCP and $\mathrm{BPO}$ and crosslinked at $150{ }^{\circ} \mathrm{C}$ for $2 \mathrm{~h}$. ( $\square$ ) DCP, (O) BPO.

\section{4. 結 語}

ナイロン66栈維をDCP およびBPO で架橋処理するこ とによって，非晶領域中に架售を形成させることができ た。架橋の形成に際して，主鎖の分解をともない，結晶 領域にも影幚を与えた。架橋効率が高いBPOを用いる と、ヤング率が顕著に上界したが, 強伸度も顥著に低下 した。

\section{5. 付 記}

本研究の一部は平成 3 年度織維学会秋季研究発表会 (京都)において発表した。本研究にご援助いただたた 京都工芸䄉維大学織維学部, 筦木長男教授, 松本喜代一 助教授、ならびに京都府立大学女子短期大学部、永田 実教授に感謝します。

\section{文竬}

1. H.F. Mark, N. M. Bikales, C. G. Overberger, and G. Menges, Eds., "Encyclopedia of Polymer Science and Engineering" 2nd Ed, Vol. 4, Wiley-Interscience, New York, p. 350 (1987)

2. 箕浦有三, コム協会誌，40，820（1967）.

3. 清造 㓮, 何 文龍, 倵学誌, 45, 49 (1989).

4. 後藤邦夫,「プラスチックおよびゴム用添加剂実用 便覽」, 化学工業社, p.874,876 (1970). 